\title{
PARTICIPATION OF WOMEN IN LOCAL GOVERNANCE IN GHANA: A CASE STUDY OF ASHANTI REGION
}

\author{
T. Y. Baah-Ennumh', S. E. Owusu', J. Y. Kokor' \\ 'Department of Planning \\ College of Architecture and Planning, \\ Kwame Nkrumah University of Science and Technology, Kumasi, Ghana. \\ ${ }^{2}$ Institute of Human Settlements Research (IHSR), \\ College of Architecture and Planning, \\ Kwame Nkrumah University of Science and Technology, Kumasi, Ghana.
}

\begin{abstract}
Active involvement of women in steering and directing public affairs, including development activities, especially at the local levels is critical to the successful implementation of the Ghana Poverty Reduction Strategy (GPRS). The paper evaluates the extent to which this is happening at the district assembly levels in Ghana with a focus on Ashanti Region. General data and analysis of women's involvement in local governance in Ghana are presented as background to a more detailed study of two selected districts in Ashanti Region. Results of the national, regional and microlevel analysis indicate that broad-based participation of women in community development and governance are still lacking, in comparison with the size of their numbers. This is despite the fact that there is increasing effort to ensure that this happens. In the light of the above, a way forward is suggested.
\end{abstract}

Keywords: Gender, local government, representation, participation.

\section{INTRODUCTION}

Ghana's decentralization process provides a framework for a system of locally-controlled development and planning. By this process, democratically elected district assemblies were established and charged as the local planning authorities with responsibility for the overall development and governance of the districts. Thus, this model of decentralization places the district assemblies (DAs) at the heart of service delivery, development and democracy at the local levels. Furthermore, the GPRS commits to the transfer of roles, responsibilities and resources to lower tiers of government. Decentralization and the DAs are again central to the overall strategy in terms of the provision of local democratic governance, transparency and the greater involvement of communities (Government of Ghana, 2002):

There is, therefore, a justification for women to be massively and actively engaged in the process of local governance firstly, as citizens and for their membership of local communities; secondly, because of the share size of their numbers relative to that of men; and thirdly, as a result of their development perspective or orientation which in most cases is insightful and communi- 
tarian. Related to this, there is the controversial saying that "men have sight, but the women have the insight" (Johnson, 2002 cited in Daily Graphic, June 27, 2002)

However, national regional and micro-level analysis reveals that Ghanaian women are far from providing the vehicle for community level governance and development management. Partly, this is a consequence of low participation in the district assembly system. The women appear to lack the motivation and capacity to engage fully in the process. What accounts for this state of affairs?.

This paper addresses this question with a particular focus on micro-level analysis. First, the larger picture is provided through a presentation of a "birds view" of the global and national situation before the micro-level analysis.

\section{Data Sources and Methods}

The paper is based on an earlier research undertaken by the first author for the master's thesis in development policy and planning. The study was supervised by the third author. Subsequent data on women's participation rates in local governance is based on a review by the three authors of the records of the Electoral Commission on district level elections conducted in 1988/89, 1994, 1998 and 2002. Prior to district level elections, the state creates a common campaign platform for all contestants to present their ideas to the local electorate. Therefore, a rapid scan of some Ghanaian Dailies during the period prior to the 2002 district level elections was also undertaken by the three authors. This review was intended to capture the reported vision and strategic views of women contestants, in particular, regarding their knowledge of what needs to be done, and how this can be done for the well-being of the communities they represent at the local levels. This information appeared useful for the understanding and assessment of development perspective and orientation of women in local governance and development. It served as supporting material for this paper.

\section{RESULTS}

Overview of the Global and National Situation

Globally, women make up a little over half of the human population in most countries. They play key roles in the socialization processes in their societies especially as mothers. Through their social responsibilities for production and reproduction, they contribute significantly to development. They sustain the cohesion of their families and hence communities and experience the harsh consequences of social disruption. Globally, millions of women work as volunteers for major political parties and for individual candidates. In spite of all these, the process of governance has been male centred and until the twentieth century, women were either totally marginalized or absent in the process of governance at all national levels throughout the world.

For example, until 1893, women did not have the right to vote in any country worldwide. According to Newland (1979), New Zealand was the first country to give women the right to vote in 1893. This long period of political exclusion of women has consequently resulted in the erroneous perception that the process of governance was the exclusive privilege and universal right for men. Finland was the first country to adopt both fundamental democratic rights to vote and be voted for in 1906 for women. In the United States, women were granted the right to vote in 1920 after decades of struggle by various women's groups.

In Europe, the situation was not better. According to Bruley (1999: 82), in Britain for instance, the Representation of the People's Act 1918 allowed only women aged 30 years and over to vote. The Parliamentary Qualification of Women Act 1918 also allowed women to stand for Parliament as well as to vote but attempts to gain entry for women to the House of Lords failed. This was achieved after a long struggle by women's groups, such as Women's Suffrage Socięties, which later became National Union of 
Societies for Equal Citizenship (NUSEC) in 1920.

In Africa, the struggle for women's empowerment and rights to decision-making process has been an uphill battle against patriarchy, poverty and autocracy $(\mathrm{Nzomo}, 1994)$. The marginalization of women in governance has been blamed not only on aspects of culture of African societies but on colonial administrators and religion (Couquery-Vidrovitch, 1997).

Women however played important roles in top decision-making process in African societies. Examples of the important African women leaders were Queen Yamacouba of Sierra Leone, the Ethiopian empress Menetewab (1720-1770), Mnkabayi the first Shaka princess in 1780, and Yaa Asantewaa, the queenmother of Asante who mobilized men to fight the British in 1900 in the then Gold Coast (current Ghana). It can therefore be stated that African women have had access to governance in their traditional areas before colonialisation. However, their participation in governance during and in the postcolonial era has been low. This has been attributed to the introduction of the western process of governance with its new institutional framework as well as combined pressures of traditional practices and conformity to western values.

As a result of the gross under-representation of women in governance, efforts have been made by international and national bodies and civil society organisations to ensure the participation of women in governance at all levels. For instance, in the preamble of the International Covenant on Civil and Political Rights, it is recognized that "freedom from fear and want can only be achieved if conditions are created whereby every one may enjoy his or her civil and political rights". Part I Article I also emphasises that all people have the right of selfdetermination. By virtue of that right, they freely determine their political status and freely pursue their economic, social and cultural development
(Robertson 1997:256-257). By this provision, the UN guarantees the rights of women to participate in local governance in their various countries.

The UN convention on the Elimination of All Forms of Discrimination Against Women (CEDAW), which came into existence in 1979, is one of the international instruments that explicitly provides an adequate framework on the elimination of gender-based discriminations, corrective affirmative action and protection of women's human rights. However, Nzomo (1994:17) observes that despite its existence since 1979 , women everywhere are still struggling for recognition and upholding of their human right. This is because CEDAW has received little beyond rhetorical support by the governments who have ratified it. Some of the countries, which have ratified CE்DAW have not incorporated the international legal provisions into national laws and even with those who have done so, majority of them have not in practice translated these provisions into action. In September $4^{\text {th }}-15^{\text {th }} 1995$, the fourth world conference on women was held in Beijing. The year was one of hope for women and men as partners in development.

Apart from these efforts by the United Nations, women's groups/networks such as Development Alternatives with Women for a New Era (DAWN), Women In Development Europe (WIDE), Grassroots Organisation Operating Together in Sisterhood (GROOTS), the International Federation of Women Lawyers (FIDA), Women In Law and Development in Africa (WILDAF), African Leadership Forum (AFL) have centred their gender-related work on the need to enhance women's participation in governance especially at the local level.

On its part, the Commonwealth secretariat seeks to promote gender equality in the area of political decision-making. It urges member states to promote women's political participation at all 
levels. Consequently, the fifth meeting of Commonwealth Ministers Responsible for Women's Affairs held in November 1995 in Trinidad and Tobago recommended that member countries should be encouraged to achieve a target of not less than thirty percent of women in decisionmaking in the political, public and private sectors by the year 2005 . It also encourages countries already close to achieving this target to take the next step of striving to achieve gender balance in political decision-making by 2005 (Commonwealth Action, 1997). In a similar way, the Southern African Development Community (SADC) governments have committed themselves to have women occupy at least thirty percent of the positions in political and decisionmaking structures by the year 2005 . To show their commitment to this, the Southern African leaders signed the SADC gender declaration. (sadc@wongo.zw). In spite of all these efforts by the UN, various women's groups, regional and sub-regional groups and countries, the global situation of women's participation in governance especially at the local level is still low.

In Ghana, the situation is no better than at the global level. Ghana has a total population of $18,845,000$ comprising $49 \%$ males and $51 \%$ females. On the regional level, apart from the Brong Ahafo, Ashanti and Western regions, females outnumber males in all the regions (Ghana Statistical Service, 2002). However, Ghana has an open policy, which gives both men and women, who have the appropriate qualifications, equal access to their participation in governance. Moreover, there is no impediment in the constitution placed in the way of women contesting for or being appointed to any position under the 1992 constitution of Ghana. This is explicitly stated in Article 17(2) of the constitution which states that "A person shall not be discriminated against on the grounds of gender, race...." The present political administration has created a women's ministry in charge of women's affairs. This ministry has been instrumental in the promotion of women in governance especially at the local level.
In spite of these conditions, the numbers of women participating in decision-making within the various structures in local governance in Ghana remains low. In terms of quantity, women are grossly under represented in local governance. In 2002, out of a total of 7,700 assembly members of the then 110 District Assemblies, only $5 \%$ were women. On the other hand, there is a general perception that women's impact in the decision-making process at the local level is generally weak.

Yet, many women played very significant roles in the struggle for independence. Market women and other individual women worked tirelessly as supporters and financiers of the Convention Peoples Party (CPP) and contributed enormously to the attainment of Independence in 1957. Despite their low level of literacy, the women demonstrated a great capacity for the struggle and were much more obstinate than males and quicker to use any weapon, traditional or modern, against Colonialism (Coguery-Vidrovitch, 1997). Nkrumah in his autobiography openly acknowledged women's substantial contribution to the anti-colonial struggle in the following words;

"Much of the success of the Convention Peoples Party has been due to the efforts of women members. From the very beginning women have been field organisers. They have travelled through innumerable towns and villages in the role of propaganda secretaries and have been responsible for the most parts in bringing about the solidarity and cohesion of the party". (Nkrumah, 1957).

Nkrumah also acknowledged the two women supporters who hid him when rumour was rife of the arrest of the six United Gold Coast Convention leaders. He admitted that, it was actually during this period of hiding that most of the plans for independence were hatched. It is therefore believed that, had it not been for the courage of these women, Ghana's independence 
could have been delayed. According to Tsikata (1997) market women were very important players in cocoa hold-ups and boycotts of European goods during the colonial era. It can therefore be said that, in the pre-independence era, women formed the hub around which all social and political activities evolved and contributed greatly to Ghana's independence.

After independence, attempts were made by the CPP government under Nkrumah to redress gender discrimination through Affirmative Action in the political and social spheres. Even though women played significant roles in the struggle for independence, they were under-represented in governance. As a result, the Representation of the People Act was passed in 1959 to make provisions for the election of women into the National Assembly in 1960. Ten seats were therefore reserved for women in the National Assembly. Consequently, ten women were elected as Members of Parliament in the first sitting of the first parliament (ISSER/DPPC, 1998). The literature on the participation of women in governance acknowledges the enormous efforts the various governments after independence made to involve women in governance and the significant roles the few women who were involved played. In 1975, in response to the UN's call for governments worldwide to set up national machinery for women, the National Commission on Women and Development (NCWD) was set up by the National Redemption Council Decree (NRCD 322).

In the Third Republic, five women were retained from a total of twenty candidates who stood in nineteen constituencies. However, because the market women were blamed for economic problems of the Acheampong and the Akuffo regimes, major markets in Accra, $\mathrm{Ku}$ masi and Tamale were demolished during the 1979 coup d'état. This was in sharp contrast to the First Republic, which used the support of market women. Again, this was against the objectives of the UN's declaration on women. This could have contributed to Ghana's late ratification of CEDAW in 1985, six years after it came into existence.

The decentralisation of governmental system in 1988 was to open the floodgates for women's participation in local governance, but this was not taken advantage of in any significant way by women in Ghana (Grant 1993). In the district assemblies that were constituted in 1989 under PNDCL 207, out of 6,907 assembly members, only $6.6 \%$ were women. Majority of these women were appointed rather than elected. Of the 110 District Secretaries appointed in 1988, only eight were women. In 1994, women made up three percent of the elected members and this rose to five percent in 1998.

In 1998, out of 110 District Chief Executives, only 12 were women. Women also constituted 24 percent of those in local government. In 1999, there were only three women (i.e. 3.6 percent) among the 110 District and Metropolitan Coordinating Directors and only three of the 110 presiding members were women (OffeiAboagye, 2000).

Information on women in local governance in 2002 just before the local level elections were as follows: out of 7,700 members of the 110 district assemblies, $385(5 \%)$ were women; seven out of 103 DCEs were women; none of the seven Metropolitan and Municipal Chief Executives was a woman and majority of the $30 \%$ appointed Assembly Members were men (Hagan, 2002). These figures indicate that there is still a long way to go in achieving a good participation of women in the decision making process at the local level.

In an effort to address this problem, the current government as a matter of policy aimed at increasing appreciably the numbers of women in decision making at the level of district assemblies by directing that all Metropolitan, $\mathrm{Mu}$ nicipal and District Assemblies reserve 50\% of the membership of the $30 \%$ quota for govern- 
ment appointees for women. The total number of female government appointees in the 20022006 District Assemblies was therefore 1,231 against 2,281 males. The number of women who filed for nomination in 1998, was 580 as compared to 981 who filed for 2002. Whereas only 199 or $34 \%$ of the women won in the elections in 1998, 368 women won in 2002. Although the number of elected women to the District Assemblies increased by $4 \%$ in 2002 , it is still considered low. This is irrespective of the generally low turn-out of registered voters at the district level elections since 1988 as indicated on Table 1.

Table 1. Total Turn-out of Voters at the District Level Elections 1988/89 - 2002

\begin{tabular}{cc}
\hline Year & Voter Turn-out (\%) \\
\hline $1988 / 98$ & 57.4 \\
1994 & 29.3 \\
1998 & 39.6 \\
2002 & 36.3 \\
\hline
\end{tabular}

Source: Nketsiah, P. Daily Graphic, March 9, 2005

Several reasons have been attributed to this trend of low women participation in local government. A micro-level analysis highlights these reasons.

\section{The Ashanti Regional Analysis and Micro- level Studies}

The study was conducted in 2002 and was limited to two assemblies in the Ashanti Region. These were Kumasi Metropolitan Assembly (KMA) and Ejura-Sekyedumase District Assembly (ESDA). The former is a metropolitan area and the latter a rural district. The overall objective of the study was to find out whether the general picture of low participation of women in local governance could be confirmed in the Ashanti region. Consequently, the study sought to determine the breadth (numbers) and depth (quality) of the participation of women in the two assemblies and to investigate the challenges they face.

The Ashanti Region has a population of $3.6 \mathrm{mil}-$ lion, comprising 1,818, $000(50.3 \%)$ males and $1,795,000(49.7 \%)$ females. Unlike the national situation, males slightly out number females in this region. It is the most populous region in Ghana with $19.1 \%$ share of the national population. There are eighteen districts in this region (Ghana Statistical Services: 2002).

As a predominant Akan society, the matrilineal system, which accords women high status and significant social and political influence, is practised. The matrilineal decent system of inheritance is the basis of the Ashanti social structure. This system therefore raises the status of women. In the traditional system of governance, the Ashantis have a monarchy whose king is chosen by a queen mother. The Queen mothers play important roles in local governance despite the fact that they are not supposed to meddle in politics. They occupy remarkable positions in the courts of the chiefs and are generally important in Ashanti society.

In spite of the position of women in the Ashanti culture, and their roles in the development of the region, women are under represented in the modern system of governance. In 2002, there were only two women members of parliament out of a total of thirty three and only one woman District Chief Executive out of the eighteen in the region. There was no female Presiding Member in all the district assemblies. The total number of assembly members in the region was 1,187 , out of this $1100,(92.67 \%)$ were males and $87(7.3 \%)$ females. The total number of elected assembly members was 840 out of which 807, (96.1\%) were males and 33 (3.9\%) were females. As indicated on figure 1 , the percentage of women appointed is only $5 \%$ while that of men is $25 \%$. These add up to the stipulated $30 \%$ government appointees. 
Fig. 1 Representation of Assembly Members in Ashanti Region

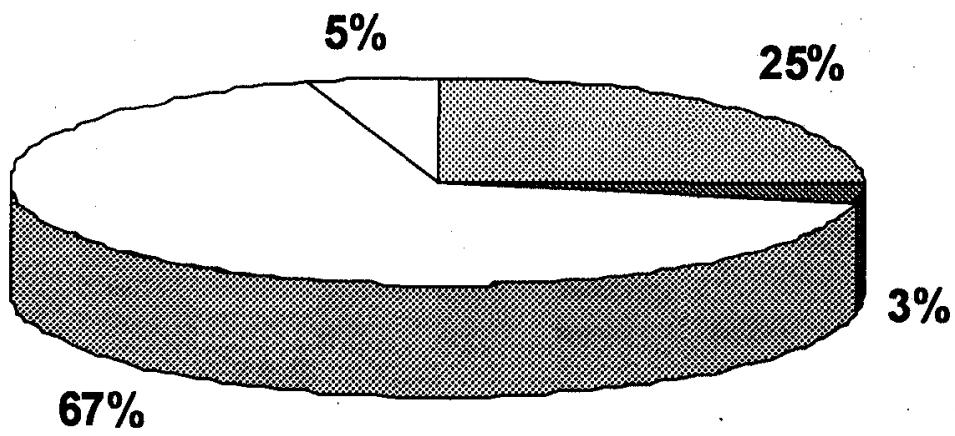

Source: Data from Field Research May 2002

A. M-Appointed Men

E. M-Elected Men
E. $W$ - Elected Women

A. $W$-Appointed Women

Table 2. Nomination Statistics for $\mathbf{2 0 0 2}$ District Assembly Level Elections-Ashanti Region

\begin{tabular}{|l|c|c|r|r|r|c|}
\hline \multicolumn{1}{|c|}{ Location } & $\begin{array}{c}\text { Electoral } \\
\text { areas }\end{array}$ & $\begin{array}{c}\text { Total No. of } \\
\text { Contestant }\end{array}$ & Males & $\begin{array}{c}\text { Percentage } \\
(\%)\end{array}$ & Females & $\begin{array}{c}\text { Percentage } \\
(\%)\end{array}$ \\
\hline Ashanti & 840 & 2,737 & 2,525 & 92 & 214 & 8 \\
KMA & 60 & 298 & 286 & 96 & 12 & 4 \\
Ejura-Sekyedumasi & 36 & 95 & 93 & 98 & 2 & 2 \\
\hline
\end{tabular}

Source: Electoral Commission, Ashanti Region, 2005 
Table 3 , indicates that the total number of elected assembly women currently is $(9 \%)$. There has been an increase of only about $5 \%$ which is still low.

Table 3. Number of Elected Assembly members in the 2002 District Assembly Level Elections-Ashanti Region

\begin{tabular}{lcccccc}
\hline \multicolumn{1}{c}{ Location } & $\begin{array}{c}\text { Electoral } \\
\text { areas }\end{array}$ & $\begin{array}{c}\text { Total No. } \\
\text { elected }\end{array}$ & Males & $\begin{array}{c}\text { Percentage } \\
(\%)\end{array}$ & Females & $\begin{array}{c}\text { Percentage } \\
(\%)\end{array}$ \\
\hline Ashanti & 840 & 840 & 762 & 91 & 78 & 9 \\
KMA & 60 & 60 & 55 & 92 & 5 & 8 \\
Ejura-Sekyedumasi & 36 & 36 & 35 & 97 & 1 & 3 \\
\hline
\end{tabular}

Source: Electoral Commission, Ashanti Region, 2005

In the 2004 parliamentary elections, 16 women contested out of a total number of 158 contestants. Only 5 out of the sixteen women won the election and are presently members of parliament.

Considering the total representation of Assembly Members in the Ashanti Region and comparing the number of men and women in the assemblies, it is evident that women are woefully under-represented. The membership of the district assemblies comprised 70 percent elected members and 30 percent appointed members. Only 3 percent of the elected members were women and 5 percent of the appointed members were women. The representation of women against men in all the eighteen district assemblies in Ashanti in 2002 indicated that in terms of quantity, the participation of women in local governance was low.

Given the fact that the matrilineal system of inheritance practised in Ashanti favours the position of women and also the fact that women are influential in the appointment of chiefs, one would have expected a higher representation of women in local governance. One therefore wonders what the underlining factors are. The underlining factors are discussed in the following sections on the Kumasi Metropolitan Area and the
Ejura-Sekyedumasi which constituted the microlevel studies.

Kumasi Metropolitan Assembly (KMA) KMA has a total population of about 1.2 million. It comprises of $587501(50.1 \%)$ males and 583, $810(49.9 \%)$ females. It has four submetropolitan district assemblies: the Asokwa, Bantama, Manhyia and Subin. The total number of the assembly members in 1998-2002 including members of parliament and the Metropolitan Chief Executive was 87 and comprised of six elected and appointed women (7\%) and 54 $(85 \%)$ men. The remaining $8 \%$ were members of parliament and the Metropolitan Chief Executive who are members without vote. Of the total, fifty-six were elected members and twenty-four were government appointees. The elected women constituted $7 \%$ while men were $93 \%$. In the 2002-2006 district assembly however, the elected women constitute $8 \%$. This indicates a marginal increase of $1 \%$. Of the twenty-four appointees, only $8 \%$ were women while $92 \%$ were men. Women were underrepresented in the assembly, and this emphasised the observed low trend of women's representation in the assemblies. The Presiding Member was a man and no woman was a chairperson of any of the four submetropolitan council. The picture as shown in figure 2 is not different from that of the region. 
Fig. 2: Kumasi Assembly Members Representation

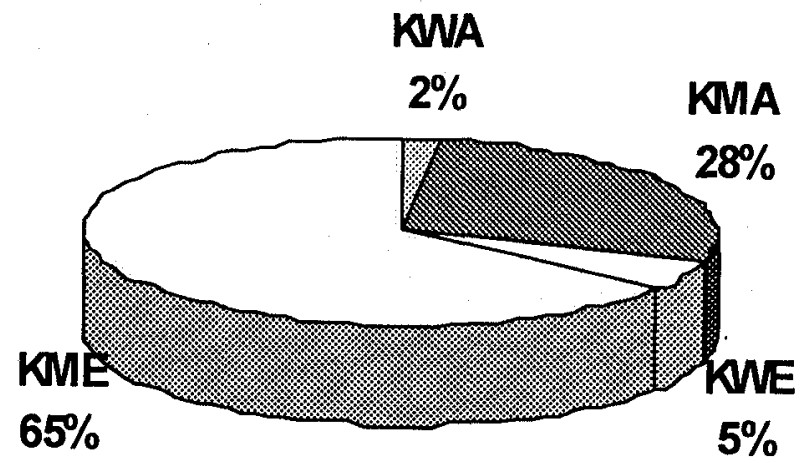

Source: Data from Field Research, May 2002.

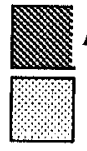

KWA-Kumasi Women Appointee

KWE - Kumasi Women Elected

\section{KMA-Kumasi Men Appointee}

KME - Kumasi Men Elected

\section{The Depth of Women's Participation}

The extent of women's participation was assessed in the following aspects;

- The frequency of their attendance to meetings,

- Their participation in deliberations at assembly meetings,

- Level of participation in their communities,

- Participation of women in general community projects.

The survey revealed that the women were punctual and regular at assembly meetings. They also contributed or actively participated in deliberations. The women respondents were motivated by the need to get involved in the leadership of their communities to correct inefficiencies and lack of accountability.

The extent of participation of the few women in the assembly was high. However, the fact that there was no woman at key position in the assembly, such as, chairperson of sub-committees,
Presiding Member, Sub-metro chairperson and Member of Parliament, limited the extent of their participation at the top level.

\section{Obstacles to Women's Participation in Local Governance}

On the issue of obstacles, the main ones identified were financial, cultural and the multiple roles of women. Seventy-five percent of all the respondents identified financial constraints as the major obstacle that has contributed to the low participation of women in local governance. This supports the fact that lack of money impedes the participation of women in local governance. In order to win elections, one needs substantial amount of money to carry out extensive campaigns through the printing of posters and other campaigning logistics as well as paying for individuals in the campaign tcam. It also involves time, which means foregoing time spent on income generating activities in order to embark on effective campaigns. 
Baah et al.

Some of the cultural obstacles mentioned in the course of the survey were religious, the process of socialisation in the various communities, the perceptions of the society about the role of a woman and education. Sixty-two percent of all the respondents identified the socialisation proccsses which are basically biased in favour of males as the main obstacle. All the five assembly women at the KMA were Middle School Certificate holders. Low self-esteem, shyness and lack of confidence were also associated with the nature of socialisation in the district. Like the situation in most African societies, right from birth, the society instils the idea of male superiority and female inferiority on the mind of the child. This together with gender stereotyping of roles have contributed to the lack of interest and general apathy of women in the process of local governance. All the five assembly women were involved in commercial activities. Their ages ranged between 40-59 Multiple roles of women was identified as the main cultural obstacle that had given rise to their low participation in local governance in KMA, approximately $85 \%$ of respondents attested to that. To eliminate this obstacle, the assembly indicated that it was collaborating with the women organisations, such as FIDA and NCWD, to sensitise women to take up the challenge of being involved in the governance of their locality.

\section{Ejura-Sekyedumase District Assembly (ESDA)}

The Ejura-Sekyedumase District has a population of 81,109 of which $52 \%$ are males and $48 \%$ are female. It is predominantly a rural district (Ghana Statistical Services, 2002). The total population of the assembly members was 52 of which $8 \%$ were women and $92 \%$ were men. Women constituted $4 \%$ of elected members and men $96 \%$. Of the sixteen appointees, only $13 \%$ were women and $87 \%$ were men. Women were underrepresented in the ESDA assembly. However it was better than that of KMA. The Presiding Member was a man and only one woman was a chairperson of a sub-committec, i.c. the Social Services Committee. In the 2002-2006 district assembly however, women constitute only $3 \%$ of the elected assembly members. Contrary to the situation in KMA, there has been a $1 \%$ decrease.

Fig. 3 Ejira Sekyere-Dumase Assembly Members Representation

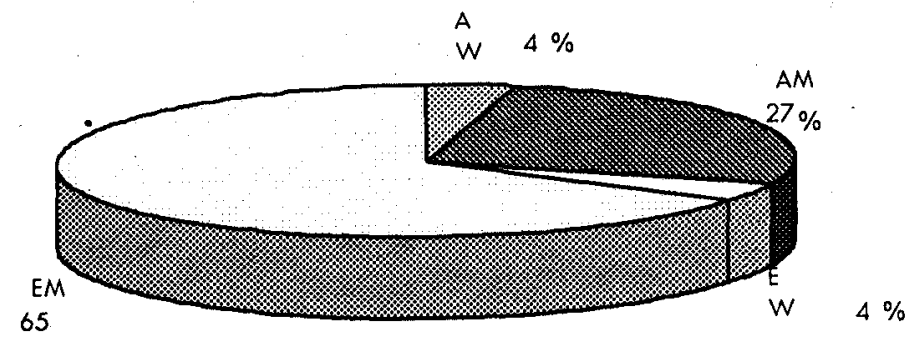

\% Source: Data from Field Research, May 2002

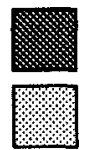

A. $W$-Appointed Women

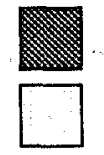

A. M-Appointed Men

E. $W$-Elected Women

E.M-Elected Men 
The Depth of Women's Participation

The extent of women's participation was also looked at from the four perspectives that those in KMA were considered. The study reveals that women were punctual and regular at assembly meetings and they contributed or actively participated in the deliberations. On the question of the motivating factors that led to their involvement in local governance, all respondents indicated that it was the urge to help in the development of their communities. On the question of the participation of women in general at the community level, the survey revealed that women in the various communities in the district did not participate actively in community projects. The main concern was about the lack of interest of women in communal activities.

\section{Obstacles to Women's Participation in Local Governance}

On the issue of obstacles, the main ones that were identified were financial, cultural, the multiple roles of women, women's attitude to the process of governance, lack of confidence on the part of the women and the demanding nature of the assembly work. These were similar to the factors identified in the study of the KMA. However, $98 \%$ of all respondents identified religion as an important obstacle: This is a predominantly Muslim district. On the measures being taken to eliminate these obstacles, it was found that the assembly was collaborating with women's groups in the district to embark on projects to help raise the status of women. Unlike the KMA, two of the women were civil servants and one is the political and administrative head of the district while the remaining two were engaged in commerce. Their educational background ranged from basic to tertiary. It can therefore be said that in spite of the fact that ESDA was predominantly a rural district, women in the district assembly had higher education and varied occupational backgrounds than those in KMA. The ages of the women in local governance in ESDA ranged from 30-69.
Findings and Way Foreword

It is clear from the review of literature and the case studies that women are generally underrepresented at all levels of governance from international to the local levels. In spite of the efforts made by various women's groups and governments, women's participation in local governance has been low.

At the local level, the study reveals that the legislations and policies to enhance their participation have made no significant change in their levels of representation and participation in governance. Women were woefully underrepresented in both KMA and ESDA, which are predominantly urban and rural respectively. There were many obstacles which impeded women's participation, but the extent to which these obstacles impeded women's participation varied in each of the districts. In general, women in the two districts appeared to lack interest in the process of governance, yet the few women in the two District Assemblies were considered effective participants. Efforts being made by the District Assemblies and women's groups do not seem to help increase women's participation hence the need to find new ways of solving the problem.

What should then guide future intervention? Based on the findings, the following recommendations are made in order to guide policy makers and all stakeholders in their efforts to enhance the participation of women in local governance.

(i) It has been established that all the efforts being made by individuals, international organisations. women's groups and national governments have not much changed the situation of low representation of women in local governance. Legislations, conventions and policies are made at conferences and other meetings and declarations made without inputs from the majority of the primary stakeholders. They therefore remain as slogans for politicians and technocrats. Also, 
these documents are hardly translated into action and therefore have little meaning to the majority of the stakeholders. The topdown approach of holding workshops and putting up sensitisation advertisements through the print and electronic media have not worked hence the need to consider the bottom up approach. The problem of low representation and participation of women in governance should be tackled at the grassroots on interpersonal levels to ensure effectiveness. Sensitisation programmes or workshops should not be mounted only when elections are about to be held. It should rather be a continuous activity and tailored to the socio-cultural orientation of the target groups. They should therefore be community based since perceived obstacles may differ from one community to the other as revealed in the case study of the two districts (KMA and ESDA). Women's groups, such as FIDA and the Ministrics of Women and Children Affairs and the Ministry of Local Government and Rural Development should collaborate to ensure unity of purpose. Coming together and collaboration among them will keep them focused at a lesser cost in achieving their common goal.

ii) District Assemblies should make the requisite effort to implement the provision in the Local Government Act 1993, Act 462, which entreats all Assemblies to provide pre-school facilities in all communities. This will help to change attitudes and lighten the multiple roles of women in the reproductive age, who were observed not to be much involved in the district assembly work.

iii) Civic ediucation on the district assembly concept and the nced for women's participation should be multifaceted. It should be targeted at specific groups such as pupils and other youth in schools, religious organisations and small neighbourhood groups.
Religious and opinion leaders in the neighbourhood should be involved in this effort.

iv) The national government and civil society organisations should intensify efforts to educate women on their reproductive rights and ensure that laws of reproductive rights of women are enforced. This will help reduce the burden of having many children and therefore reduce the multiple roles of women to enable them get adequate time for other decision-making roles in their communities.

\section{CONCLUSION}

Generally, there is a low representation of women in local level governance. This is attributed to a host of factors. The extent, to which these factors become obstacles however, vary from place to place and have socio-cultural undertones. Various efforts have been made by international organisations such as the UN, Women's groups and the Government of Ghana but these have had little impact on the trend of low representation and participation. The situation can be improved if interventions and initiatives are made at the grassroots and at the interpersonal level and increase in the enrolment of females at the various' levels of the educational system which can influence shift in mindset.

\section{REFERENCES}

Brucly, S. (1999). Women in Britain Since 1900. London, Macmillan Press Ltd.

Commonwealth Action (1997). Regional Symposia: Women- Local Government. http:// www. Clgf.demon.co.uk

Coquery-Vidrovitch C. (1997). African Women. A Modern History. Oxford, West View Press.

Electoral Commission (2005a). Nomination Statistics for 2002 District Assembly Level Elections in the Ashanti Region. (Unpublished). 
Electoral Commission (2005b). Number of Elected Assembly Members in the 2002 District Assembly Level Elections in the Ashanti Region. (Unpublished).

Government of Ghana (1992). The Constitution of the Fourth Republic of Ghana. Accra.

Government of Ghana (2002). Ghana Poverty Reduction Strategy, Accra.

Government of Ghana (1993). Local Government Act, 1993, Act 462. Accra.

Government of Ghana (2002). Report on 2000 National Population and Housing Census. Accra, Ghana Statistical Services.

Grant, M (1993). Decentralisation and Women's Participation in Local Politics in From Centre to the Grassroots Vol.4. Accra.

Hagan, E. (2002). . A Welcome Address at the Training Workshop for Prospective Candidates for 2002 Local Government Elections. Unpublished. FIDA.

ISSER/DPPC (1998). Women in Public Life in Ghana, Accra

Johnson C. (2002). Men have Sight and women have insight. Daily Graphic. (Accra). June, 27 p. 10
Newland, K. (1979). The Sisterhood of Man. New York, W.W. Norton and Company.

Nketsiah, P. (2005). Let's Participate in Local Governance. Daily Graphic. (Accra). March 9.

Nkrumah, K. (1957). The Autobiography of Kwame Nkrumah. London, Nelson and Sons Ltd.

Nzomo,,M. (1994). The Status of Women's Human Rights in Kenya and Strategies to Overcome Inequalities. Issue A Journal of Opinion, Vol. XXII (2), cd Hawk, B. G., Michigan, McNaughton and Gunn Lithographers Inc.

Ofei-Aboagye, E. (2000). Promoting the Participation of Women in Local Governance and Development: The Case of Ghana. ECDPM Discussion Paper 18, Maastricht, ECDPM.

Robertson, D. (1997). A Dictionary of Human Rights. London, Europa Publications.

Tsikata, D. (1997). Gender Equality and the State in Ghana: Some Issues of Policy and Practice in Engendering African Social Sciences. Ed Imam Ayesha et al. Wiltshiorte, Anthony Rowe Ltd. 